\title{
Shared authority in confirmation work in the Evangelical Lutheran Church in Denmark
}

\author{
Av Anna Døssing Gunnertoft \\ Anna Døssing Gunnertoft, (f. 1980), PhD student, School of Culture and Society, \\ Aarhus University, Jens Chr. Skous Vej 3,8000Aarhus, Danmark anna@cas.au.dk \\ https://orcid.org/0000-0002-6636-8313
}

Keywords: confirmation work, Christianity, learning process, shared authority

\section{InTRODUCTION: Shared AUTHORITY}

It is the first confirmation lesson. The ministers, Laura and Steen, welcome confirmands and parents. They are all invited to participate in a discussion about their personal images of God. As an inspiration the ministers have placed different photos on the floor. There are photos of nature, buildings, and different human situations. The task is to find a photo that is related to one's own image of God. «There are no right or wrong answers», the ministers say. "As ministers we don't know any better than you [confirmands]. Even though we've studied theology and read a lot of books in German, Greek, and Hebrew, we've just studied what other people have said about God. All answers are of equal value».

After group work and discussion at the tables, Laura says that a child may have an image of God as a Santa Claus figure sitting on a cloud. This image will not be helpful in the long run. Therefore, the ministers wish to help the young people to change such images of God and give them a new language about God (Observation September 2th 2018).

The example shows how the ministers share their authority with the confirmands and the parents. They follow a modern pedagogical trend towards symmetry between teacher and pupil in learning; however, their learning method is also religiously motivated. With respect to the experiential dimensions of religion, they confess that they are not all-knowing experts, for the confirmands may know as much about the subject as them. In the photo-exercise there are no right or wrong answers. All participants are equal. But this is not the whole picture. Laura indicates that the ministers know more about the image of God after all: they can help the confirmands to reach an understanding of the divine that can last through all phases of life. Thus, the ministers have reasons to take back authority under circumstances evident for most of the participants in the meeting. Authority is negotiated or shifts 
during the learning process. Sometimes it is shared. Sometimes the ministers seek to take it back to bring their experience and knowledge into the learning process. Negotiation means here the initiative on the part of the ministers to open an understanding for the confirmands that they are as qualified as the ministers to use authority in connection with relations to God.

Sharing authority is a hot subject and has been for some time (Freire 1970; Shor 1996; Dysthe 1997, 2012). When this tendency is introduced in the church, there is a special dilemma: the potential conflict between equality in religious learning and the obligation to mediate a system of traditional doctrine or the tension between experiential theology and dogmatic systems and rules. The question, therefore, is how authority is shared and negotiated in confirmation training in the Evangelical Lutheran Church in Denmark (ELCD)? This will be investigated through an analysis of two cases from confirmation training in the ELCD. The cases demonstrate the ministers' acceptance of shared authority in practice.

\section{The Danish context}

The cases analysed here stem from a study of confirmation work in the ELCD known as «folkekirken» (the people's church). The relationship between traditional Danish culture and the ELCD is strong. In January 202074.3 percent of the Danish population were registered members. As «folkekirke», the ELCD encapsulates theological positions, meanings, opinions, scepticism and conflict. Some church members are deeply engaged, others only attend church at family related rituals such as baptism, confirmation and funerals. The church is traditionally conceived as open for the whole nation, but the ELCD is also a confessional church, a religious community (Nielsen and Kühle 2011:173-188). The curriculum for confirmation is stipulated in the law for confirmation (September 2014).

The public school in Denmark has not had confessional religious education since 1975 , but it is decided by law that the preparation takes place in school time and located at church facilities, when the confirmands are in seventh or eighth grade $^{1}$ during which time no other religious learning takes place in school.

\section{THEORY}

\section{What is authority?}

From the opening story the ministers display at least three types of authority: 1) a traditional role as teacher and facilitator, planning and selecting (the photoexercise as group work) 2) a distinct role as the trained expert on religion displayed in correcting and nuancing discussion as well as in lecturing (... we have studied theology and read a lot of books...); and 3) a more personal role as an experienced religious person (... related to one's own image of God. «There are no right or wrong answers»).

1 School law $\$ 53$ cf. $\$ 40$, section. 2 , no. 4 , and $\$ 44$, section. 2 , no. 1 .

https://www.retsinformation.dk/eli/lta/2019/823 
Max Weber (1925/1964) «defines authority as the probability of a person gaining voluntary obedience from others» (Pace, Hemmings and Bixby 2006:2) and divides the concept into three types: 1) rational legal authority (institutional or expert domain), 2) traditional authority (the way it has always been), and 3) charismatic authority (extraordinary abilities and capacities). Judith Pace and Annette Hemmings discuss the typology stating that:

"Although the differences between ideal types are crucial, Weber (1925/1964) pointed out that in the real world they do not exist in their purest forms. Those who exercise authority usually appeal to mixed claims to legitimacy» (2006:3).

Kirstine Helboe Johansen and Marie Vejrup Nielsen examine representations of pastoral authority among mainstream church members in the ELCD (2015). In their analysis they use Weber's typology of authority and deploy it freely deviating from the original meaning to illuminate the different types of authority ascribed to the ministers by bridal couples (Johansen and Nielsen 2015:229;238-239). They "conclude that the representation of pastoral authority can be described as 'relational authority'» (Johansen and Nielsen 2015:227). It means that Weber's typology is followed initially, but in the end the couples' choice of minister is subjective depending on a relational authority, which might be understood as a fourth type or as a mixed form of authority. I also deploy Weber's typology to illuminate the concept of authority in relation to the ministers' pastoral authority, but I work with another aspect of pastoral work, namely training for confirmation. Here the focus is on the ministers and how they work and apply authority in the learning fellowship.

Weber's typology covers the ministers' authority based on the rational legitimate authority (their education and representation of the institution) and tradition (as it has always been done). The ministers act with the authority of longstanding tradition. The trained pedagogical expert has the skill of rational argumentation, and the professional theologian knows the use of actual and precise scientific vocabulary pertaining to authority. As somewhat different from Weber, the charismatic type in this article concerns authenticity and personal experience and may be found among the participants, ministers as well as confirmands.

My aim in deploying Weber's typology is not a theoretical contribution to the typology, but solely to decipher different aspects of authority and the sharing of authority in the classroom. Though reality is always 'messy' (Ideström and Kaufmann 2018:50), typologies - when not mistaken for reality - are strong tools for nuanced analytical insight. 


\section{How is authority negotiated?}

The three aspects of authority are negotiated differently: 1) as theological experts, the ministers make the room available for those who want to take it over for an argument in a discussion or a conversation; 2) the minister's classroom leadership is both traditional and professional authority as pedagogical expertise. The material space is here divided for different use as group work, walk-and-talk, and drama; and 3 ) the charismatic part is open for authentic and personal consideration or experience as first-hand knowledge. Thus, negotiations of different aspects of authority allows the confirmands to gain authority in different parts of the learning process: they need to take charge of learning in peer sessions without the ministers being directly present, they are invited to argue for their point of view, and they are taken seriously in their personal experience.

\section{Relationship between Weber's typology and religious learning modes}

Morten Holmqvist and Geir Afdal distinguish between three basic metaphors for religious learning (2015:15-16): 1) logic of belief - a certain body of doctrine and narratives to be known and believed; 2) logic of practice - enacted religion or religion as something done; and 3) logic of faith - religion as feelings and moods such as awe and wonder (religious experience).

«Logic of belief» can be compared to Weber's first type of authority «rational legal» which is institutional as expressed in the office as minister. Weber's second type «traditional authority» (as things are and always have been done) has similarities to both «logic of belief» and «logic of practice». Most interesting in this comparison of similarities between authority and learning theory is «logic of faith» and Weber's "charismatic-relational authority», which are both connected to special insight as a personal gift of authentic nature. What takes place is a movement in and out through different modes of learning: 1) acquired ability to know and use religious concepts as tools for thinking, 2) faith through enactment of religion, and 3) a personal religious insight through experience.

This scheme of similarities indicated between types of authority and modes of learning opens for questions to be examined. Is there a correspondence between logic of faith and charismatic-relational authority to be found in the observed material of the cases? In the light of the two types of authority indicating asymmetry between teacher and pupil, namely Weber's first and second type, the question can be raised about degrees of shared authority as described in the ministers' opening session, where the ministers alone have chosen the photos.

The relationship between religious learning and authority may be seen through different terms derived from the concept of authority. In connection with learning as acquisition or as logics of belief, there is an opening towards the 
concept of authorization which was earlier connected with confirmation e.g. as giving the right to participate in the Lord's Supper. Today baptism and a certain acquired epistemic knowledge gives the right to be confirmed in the ELCD as stipulated in the Confirmation Act of $2014^{2}$. Also, confirmation itself may be seen in connection with a concept related to authorization: an empowerment as seen in the original Confirmation Act (1736 b4-5) and the ongoing discussion of the meaning of confirmation (Gunnertoft 2020).

\section{Shared authority as a pedagogical concept}

In the field of pedagogy, shared authority is a well-known topic, and there are works about negotiating authority through polyphony and dialogue, e.g. Olga Dysthe's "The Multivoiced Classroom" (1997). She is inspired by Bakhtin's understanding of dialogue. For Dysthe, multi-voicedness (polyphony) is a means for development and progress of learning as well as something furthering equality. But the asymmetry between teacher and student is not abolished. In the learning theory of Yrjö Engeström, the starting point is that neither teacher nor pupils know what the result will be, but the symmetry is a result of a development in the learning process. They help each other with discussion and individual contributions to develop knowledge necessary for the final result. Multi-voicedness and contradiction are here principles present in the learning fellowship or activity system as analytical tools (Engeström 2010:136-137). Also, James V. Wertsch's work (1998) has been meaningful for my work with dialogue and sharing of authority.

Jos de Koch and Ronelle Sonnenberg from Protestant Theological University, Amsterdam, work with the relationship between religious learning and religious experience as rooted in human bodies (2012). The focus is on concrete experience, acts, and rituals, not cognitive processes. The logic of practice is here a primary way to religious learning, experience, and shared authority in youth work.

In recent years, the multi-voiced classroom has been a key topic in Scandinavian research on religious education. In 2018 the Norwegian journal Prismet had a themed issue on the subject. Bernd Krupka, scholar in pedagogy and religion, offers an analysis of three textbooks about confirmation work in the Norwegian Church in the article, «With room for different voices?» (2018). He looks for polyphony, but finds a presentation of traditional religious teaching, whereas two Norwegian dissertations - Fredrik Saxegaard on ministers' leadership in the church (2017) and Morten Holmqvist on confirmation work (2015) - share findings similar to the topics explored in this article. The dissertations are a part of the LETRA-project led by professor Geir Afdal. This project has produced important empirical research on learning trajectories among young people and professionals in the Church of Norway (Ideström and Kaufmann 2018:28). Saxegaard points to

2 Confirmation law of 2014, chapter 3, \$ 7: https://www.retsinformation.dk/eli/lta/2014/1027 
the ministers' role as leaders and agents of change. He refers to Weber's typology and connects the ministers' role with the sharing of authority: «'Lifestyle' may also be seen as closer to Weber's authority form based on charisma and tradition, whereas 'job' relates to the legal-rational and functional-rational base» (Saxegaard 2017:197). This aspect of the minister as leader in the learning process is also evident in the cases studied here; however, in the present article the ministers' leadership is seen in their negotiation of shared authority with the confirmands. Holmqvist's work is a contribution in relation to confirmand work. While his focus is on the relationship between ministers and confirmands, the present article focusses on the ministers in their confirmation work. By adding Weber's typology, it is possible to nuance the ways in which different degrees of authority are shared and how this is achieved in the Danish confirmation work.

\section{Religious knowledge and the mystery of God}

Why do the ministers state that they do not know better than the confirmands in spite of their theological training? The answer is as mentioned that their professional knowledge is only second-hand - what others have experienced - rather than first-hand or authentic experience (Jarvis 2008:557): «Perhaps the significant fact is that we all have these experiences» (Jarvis 2008:566). And, as Afdal writes with reference to Jarvis, "Religious learning is conditioned by religious experiences. Religious interpretations, tradition, and dogmatics are secondary» $(2013: 107)^{3}$. Holmqvist refers to an example of an authentic experience from the Norwegian curriculum for the teaching of youth (2015:117). He references an account about three-year-old children standing around a Christmas crib, and for them «this experience of wondering opens up for new insight that enables them to show other religious participants into the mystery of Christmas» (Holmqvist 2015:117). Thus, the children became teachers for the adults who observed the event. Holmqvist concludes: «Epistemic authority is related to authentic experiences, not to scholarly competence, and personal authority is distributed between the participants, independent of the formal role» (2015:117).

\section{Methodological approach: Study design}

The material introduced in this article is from my fieldwork in three parishes in the diocese of Aalborg. I followed six school classes and four ministers (OctoberMay 2018-2019) concluding with interviews of the ministers individually and the confirmands in groups of eight. Besides the introductory case in this article, two primary cases are chosen from one church. Here I found two ministers consciously working with a principle of diversity and openness as a means for learning through shared authority. The cases selected illustrate their methods and show three different

3 Translated by author 
ways for negotiating authority, a more traditional learning situation with groupwork, plenum and walk-and-talk as well as theological discussion (case one), while case two is based on participation in a drama. The cases also reveal a tension between form and contents.

My observations have been transcribed and an abductive analysis has been performed through coding of certain analytical concepts. In this process, it became clear that "multi-voicedness" was not just an analytical concept as shown by Engeström, but also a pedagogical and theological understanding of the ministers in sharing authority. Practice theory as overarching design makes it possible to see what the ministers actually do in comparison with their written programmes for the sessions.

The case study design was the basis for my work. The reason for this is that I consider this as the best way for reaching expertise in a qualitative research. The case study gives the form for context dependent knowledge which is essential for research in learning. The aim for sampling was to optimise information from the single cases in my analysis as the best usable material (Flyvbjerg 2001:79).

\section{Case one: The Parent-Confirmand meeting \\ Case description: Two educational stories}

A meeting arranged by two ministers, Laura and Steen, was held in a city church. Nearly all the confirmands (48) were present with their parents. The room was prepared with a screen for teaching and Steen welcomed the audience. The subject was the creation of the world.

The first part of the meeting involved group work. Each group consisted of three to four confirmands and their parents. The aim was to show different meanings of the concept of truth. Two stories were told and shown on the screen followed by questions for reflection and discussion. The first story was "The Boy Who Cried Wolf". A boy shouted out for fun that a wolf was coming. But there was no wolf. When people found out that the alarm was false, they did not come the second time, the boy called for help. He was alone with the wolf and cried for help in vain. In the group I attended, both parents and confirmands agreed that even though this story might never have taken place, it was still true in a moral sense.

The other story was about how a certain person might be perceived by a physician, who treated him, or by the person, who loved him. What was the truth: the medical view or the view of love? This was discussed in the group. Final agreement made it clear that the medical truth and the truth of love were equally true.

\section{Shared authority?}

What do these two stories imply about shared authority? The ministers keep their ownership over and use of artefacts and pedagogical methods (the two stories and 
group work). The authority to structure learning is traditional classroom leadership; however, the sharing of authority is only formal. The two stories indicate contradictions, but the solution of the puzzle is given beforehand as enclosed in the task. The discussion could only lead to the result planned by the ministers. The contradictions were only apparent as the stories were both true in their respective perspectives. The participants agree that the apparent contradiction can be annulled, and that two contradictory matters can both be true.

\section{Case description: The principal discussion}

After working with the two stories, a new piece of information was offered: there are two different creation accounts in Genesis in which the sequence of creation is different. In Genesis 1, man is created last; in Genesis 2 man is created first. The question was posed whether both accounts can be true. And what about the biblical creation narratives and the Big Bang theory of natural science? Can both be right? These questions about creation lead into the principal discussion: are the biblical accounts really true? According to Steen, a solution to the problem of contradiction could be that the biblical narratives deal with the "why" - why the world was created - while the scientific theory deals with the "how" - how the world came into being. The confirmands and their parents were on a walk-and-talk tour to discuss the matter. Afterwards they returned to continue their talk in the plenum.

\section{Harmony between a theological and scientific understanding of creation?}

What are the implications of the ministers' revelation of their purpose? The guidance into walk-and-talk-discussion as a new framework is again determined by the ministers as a part of traditional authority; however, the discussion is also left here to the confirmands and parents according to their own authority of rational nature.

That the ministers inform parents and confirmands about their own solution of the problem indicates their desire for the outcome of the walk-and-talk tour. It is a different situation from the two initial stories, which were to make way for the principal question about creation. What may happen is that the discussion will not be about the problem, but about the ministers' suggested solution of it. This will be a step into real sharing of authority because it reduces the ministers' statement to an object for discussion among equals.

The ministers' written study programme shows the purpose with the session: confirmands and parents should see that the Bible and the scientific account of creation do not contradict each other, and give them an opportunity to reflect over their own belief about the origin of life (March 20, 2020). The sharing of authority makes the ministers take the risk that their purpose with the session will not be fulfilled. 


\section{Case description: Discussion in plenum}

Back in the church, Steen invited all to speak their minds. Did they find harmony between the biblical accounts, and between Bible and science? The last question caused some disagreement. A confirmand boy argued that God could not have made the Big Bang, because there was no food in heaven at that time. Steen replied, "Okay, it is a physical understanding». He explained that God is outside time in eternity: «God is before time and after time». Laura added, that God is so entirely different from humans that He does not need food: «Therefore, you can believe that God has set the Big Bang in motion». One father stuck to the disagreement. Steen waited a few minutes to see if anyone else had something to add and said: «We will close here.» Laura had a final comment: «So we will ask 'why'... and you can figure out, what we think, and perhaps go home and think about it... We hope we have started something for you.»

\section{Negotiation of authority or damage control?}

What happens in a plenum? As seen, the participants did not reach agreement as they had done with the two preparatory stories. It may concern the way the ministers handled the artefact (Afdal 2013:155). The ministers' argument that science and Bible show two different perspectives, how and why the world was created, is not really accepted. One of the fathers objects to it, and a confirmand boy contradicts the idea that the two understandings of the birth of the universe can be harmonized. He takes over the authority and gives an explanation of why the biblical story cannot go together with the Big Bang, because God had no food in heaven. This is a kind of reasoning meant to be in line with the ministers' argumentation, but it is in contrast to their thinking.

The incident shows that there is a contrast embedded in the ministers' way of negotiating authority. On one hand there is openness and inclusiveness in form (walk-and-talk, discussion), but on the other hand the contents of their methods are restrictive, regulating, and delimiting when meeting opposition.

Steen's answer to the boy contains some theological technicalities probably not known to the confirmand. This makes the statement somewhat authoritarian as a change into a professional language indicating theological expertise. It can also be seen as an attempt to accommodate the boy and meet him as an equal partner in a theological discussion where the boy's physical understanding is recognized and needs a professional answer. A pastoral perspective is possible. Steen tries to expand his and the assembly's understanding into a spiritual realm. Laura's additional words about the difference between God and humanity are both in support of Steen's answer and an attempt to take an eventual sharpness out of the conflict. Yet, the ministers' answers have closed the discussion with the boy by using technical theological material, employed by experts (Wertsch 1998:69). 
The sharing of authority as the principle mediational tool appeared successful in the first part of the meeting; however, when professional language was used, the authority was no longer shared. It belonged to the experts. Steen's response, «therefore you can believe that God has set the Big Bang in motion», is the statement that closes the discussion. Since the ministers' purpose is to make the parents and confirmands see a harmony between the biblical and scientific accounts, their reaction to opposition is perhaps more damage control than sharing of authority.

\section{Case description: The evaluation}

The ministers invited the participants to an evaluation of the arrangement. «It was surprising and good», one mother said. «All present were involved», a father remarked, continuing, «It makes them [the confirmands] think instead of just having a lot of thoughts thrown in their faces». One mother was happy, because the ministers created a consciousness in them that nothing is simply right or wrong. When she herself was a confirmand, something was once and for all settled. Now the ministers created a discussion, so the confirmands could draw their own conclusions as to what they would believe. The confirmands were silent.

\section{Participation in the shared authority}

I find the most distinct example of delegating authority to be the evaluation of the ministers. Here the parents have the upper hand. They can state their opinions of the session any way they see it, because the ministers have given the authority entirely to the assembly. This is a part of the way authority is negotiated. The ministers were praised by the parents for not using authority in the old-fashioned way like the old-time authoritarian minister who defined what was right or wrong. However, this can also be seen as a restriction. The ministers are not supposed to usurp authority through their expertise or professional knowledge. The method of learning and the theological explanation were well received by the parents, but the parents' understanding of truth as wholly a relative matter goes beyond the ministers' viewpoint.

\section{An interview: Outside the shared authority}

One month later I had an interview with eight confirmand girls. They independently raised the subject of the parent-confirmand meeting and explained that they were not interested in the dilemmas discussed. They had heard enough about the Big Bang in school, now they wanted to hear about Christianity as the real thing without intellectual distance. As a girl put it. «We've come to learn what Christianity and faith are. What do the ministers themselves believe? What do Christians believe?» (interview 09.05.2019).

No doubt the ministers agreed with the girls that Christianity is not just something intellectual, but something felt and lived. Steen said: «Well, there is 
more at stake... and if we only relate to it [Christianity] intellectually... then we only open up some of the elements, but feeling something is an important part of life as a human being and thus also as a Christian... What Laura and I are trying to do, I think, is to present and represent Christian faith» (Interview 26.06.2019). But the parent-confirmand meeting had another purpose, to take away hindrances for faith, be apologetic.

The parents were pleased with the openness in the ministers' way of leading the meeting. But openness in a certain area may close another insight. The talk with the girls reveals that they felt excluded. They felt no part of the shared authority. The ministers did not examine what the confirmands wished. The young people were not interested in intellectual dilemmas about e.g. creation. They explained that they had also heard about other subjects such as love and courage as concepts, but they had difficulty seeing the relationship of these subjects to Christianity. They seemed to be looking for something to be felt, experienced, and lived. It can be concluded that the type of authority the girls wanted from the ministers, was neither tradition nor expertise. What they wanted to be confronted with was something personal, something authentic. The interview with the ministers reveals that they evidently wanted to share just that type of authority the girls wanted, charismatic authority.

All three modes for religious learning (logic of belief, logic of practice and logic of faith) can be seen as working together in a process towards religious experience. The first gives the concepts for religious thinking, the second gives the basic entrance to faith through enacted religion, and the third leads into religious experience through feelings of awe and wonder. In this scheme it appears that the girls were not really included in the enacting of faith, at least not at the time of this interview.

\section{Case two: Poor table manners in biblical CORINTH AND TODAY'S SCHOOL YARD.}

A one-day excursion with different tasks was planned for the confirmands. Here, one drama from the day is elected and analysed. In the drama as pedagogical instrument, the door was further opened for sharing authority through contradictions, multi-voicedness, and dialogue.

\section{The case: The drama in Corinth}

The place is the city of Corinth shortly after Paul's work there. Steen welcomed the confirmands to town. He was now in the role as Nicolaus, leader of the Christian congregation. He told the group about life in the congregation and about Paul's visit and his meeting with the resurrected Jesus. Nicolaus explained about the growth of the congregation and baptism of new members in the river. 
But they had a problem: they were divided, and, when they ate together, some would rather sit with certain members of the congregation than with others. Paul had sent a letter and corrected them (1. Corinthians 11:17-23). The scripture deals with the split and division in the Corinthian congregation and the disorderly way in which they conducted their meals. The last part is about the institution of the Lord's Supper.

Steen stopped his role as Nicolaus and was again the minister talking to his confirmands. He asked them about the eating together, where some of the Corinthians were excluded or did not get anything from the table:

Steen: «Have you experienced that there are some who won't eat with you? Or you won't eat with certain people?»

Four confirmands simultaneously: «All the time!» or «Several times.»

A girl: «Yes, it's that way all the time in my class.»

Steen: «All the time! How can that be?»

The girl (with low voice): «There are lots who keep some people out... Yes.»

Steen: «Do they also do that when you eat together?»

The girl: «Yes... No.. Not when you eat together, but when you eat alone and no one cares to eat with you.»

After further discussion in which two more confirmands participate, Steen

concludes: «Okay, quite a normal $7^{\text {th }}$ grade.»

The girl: «No, it is not...»

A boy hesitantly: «No... a normal $7^{\text {th }}$ grade...»

The girl adds: «...they have friends.»

Steen concludes the discussion with a "good" as he usually does; however, as the Lord's Supper is a part of the drama, he tries to bring this perspective in as a solution to the problem. He explains that in the Lord's Supper we eat together with people we have not invited and do not know - or perhaps do not like. The girl answered that when she has been at the Lord's Supper, it has only been with the confirmation class, her school mates. Steen continues; "But maybe you can use this when you have problems in the class; maybe you can eat together with people you do not like. When you eat together, you eat yourself [and the others] together [into a fellowship]". The boy answers that he does not understand this sentence. To him Steen says exactly the same twice.

The broken meal fellowship and the incomplete dialogue What happens here? As the actor jumps out of his role, he is no longer Nicolaus, but Steen, the minister, who through his questions to the young people brings the biblical story right into their lifeworld. In matters of being excluded from 
the common meal as in Corinth, the confirmands are the experts. They know the problem first-hand from the school yard, and in the conversation, they take on authority. One girl, who feels the problem very painfully, takes the lead. The minister's assumption that the exclusion from the meals in the school yard was something common for a $7^{\text {th }}$ grade class was rejected by the girl. Her vehement 'no' indicates that she saw the minister's statement as an attempt to finish a discussion just beginning by reducing her experience to something ordinary. If this interpretation is right, it explains her passionate reaction. On the other hand, her indignation may just be a result of her painful experience.

In retrospect it seems as if authority changes in this negotiation. At first the girl tells the group about her problem where she is vulnerable. She shows great confidence in the minister and opens up about her innermost feelings on a subject that is perhaps shameful for her. Here she extends the authority to Steen. That the office of the minister creates confidence is seen both by Johansen and Nielsen and Saxegaard as a part of Weber's authority as the relational-charismatic (Johansen and Nielsen 2015:229; Saxegaard 2017:197). The girl speaks with an authority based on her own experience and expects an answer of the same kind. The conversation reveals the extent of the problem as something that takes place all the time, and therefore the minister's tentative conclusion about $7^{\text {th }}$ grade issues appears as a traditional authority of a teacher, which clashes with the dramatic nature of the girl's experience. The girl takes the authority back; that she knows by experience the difference between a normal $7^{\text {th }}$ grade and her situation.

Once again the minister tries to comment on the issue; this time by using the authority of expert knowledge and religious language. He takes up the Lord's Supper from the drama to use this perspective as a solution to the confirmands' problem.

The whole dialogue reflects the way in which the minister uses his authority (both traditional and expert or institutional authority), while the confirmands use the relational-charismatic authority. The confirmands seek to be met where they are; however the result is instead a clash between different authorities. The conversation closes without a real result.

\section{CONCLUSION}

Returning to the research question: How authority is shared and negotiated in confirmation training in the ELCD. In my investigation, I found two ministers who expressed their desire to involve the confirmands in the learning process by making room for different voices and shared authority for both theological and pedagogical reasons. But it remained only method and formal appearance, not content. The ministers retained control of the learning process, purposely determining subject, questions to be answered, and the outcome. 
My most important findings are, therefore, the discovery that the ministers work in the two first types of Weber's typology, the rational legal and the traditional authority, but never in the third type, charismatic-relational authority, and this in spite of the fact that both they and their confirmands express a wish for something else. The ministers only work with religious learning as logic of belief and only partially in logic of practice, but never with logic of faith (Holmqvist 2015). They remain, therefore, to a certain extent in traditional religious learning (as in Krupka's findings), even though they are affected by modern pedagogical trends towards shared authority and polyphony. Why is that?

The answer, or part of it, may be found in their profession as ministers. Saxegaard distinguishes between the ministers' roles as job and lifestyle (2017). In the ministers' role as job, authority is connected with expertise, tradition, and institution. Here, religion becomes primarily epistemic knowledge inherited through generations, while the ministers' role as lifestyle is connected with personal experience. The confirmands express wishes to hear about this. For them, religion seems to be something personal, which is not to be acquired through education or according to tradition, but rather through lived experience. This may create more equality between ministers and confirmands, and here the ministers cannot hide behind their profession.

If the ministers really want to share authority through Weber's third type, it is important for them to avoid keeping up professional distance. Beyond tradition and epistemic knowledge religion can be brought into play for personal access, experience, and dialogue. The ministers may feel that they have reasons to protect the personal sphere of privacy both for themselves and the confirmands. Another important reason why they delimit the dialogue can be fear of harming the message they want to convey. Nevertheless, if they wish to present and represent Christian faith (interview), they need to find the right balance between all three learning modes: logic of belief, practice, and faith.

These observations, interpretations, and reflections are my contribution to the research of the symmetric perspective in religious learning. An essential help has been the consideration of modes of religious learning, especially logic of faith (Holmqvist 2015), which I connect with Weber's typology. Saxegaard's reference to Weber's typology leads to an understanding of the ministers' office as job or lifestyle. For me, the last concept may signify an opening to charismatic-relational authority in the field of learning without leaving out traditions connected with the office as ministers. However, this crossing of the borderline between two types of authority may weaken the strength and understanding of the third authority. 


\section{REFERENCES}

Afdal, Geir. 2013. Religion som bevegelse. Laring, kunnskap og mediering, Oslo: Universitetsforlaget.

Dysthe, Olga. 1997. Det flerstemmige klasserum: skrivning og samtale for at loere. Århus: Klim.

Dysthe, Olga, Nana Bernhardt and Line Esbjørn. 2012. Dialogbaseret undervisning, Kunstmuseet som laeringsrum, Forlag Unge Pædagoger.

Engeström, Yrjö. 2010. «Expansive Learning at Work: Toward an activity theoretical reconceptualization» Journal of Education and Work, vol. 14, No. 1, p. 133-156. https://doi.org/10.1080/13639080020028747

Flyvbjerg, Bent. 2006. «Five Misunderstandings About Case-Study Research», Qualitative Inquiry, 12 (2), 219-245. http://dx.doi.org/10.1177/10778004052 84363

Freire, Paulo. 1970.«The Adult Literacy Process as Cultural Action for Freedom». Harvard Educational Review, 40, (2), 248-265. https://doi. org/10.17763/HAER.40.2.Q7N227021N148P26

Gunnertoft, Anna Døssing. 2020. «The confirmation ritual in the Evangelical Lutheran Church in Denmark: conveyance of a religious experience or playacting?» Practical Theology, vol. 13, issue 6, p. 581-593, https://doi.org/1 0.1080/1756073X.2020.1777652

Holmqvist, Morten. 2015. Learning Religion in Confirmation: Mediating the Material Logics of Religion: An ethnographic case study of religious learning in confirmation within the Church of Norway. Oslo: Department of Religion and Education, MF Norwegian School of Theology.

Ideström, Jonas and Tone Stangeland Kaufmann (editors). 2018. What Really Matters. Scandinavian Perspectives on Ecclesiology and Ethnography. Church of Sweden research series. Vol. 17. Pickwick Publications, Eugene, Oregon.

Jarvis, P. 2008. «Religious Experience and Experiential Learning». Religious Education. Vol. 103. No. 5. p. 553-566. https://doi. org/10.1080/00344080802427200

Johansen, Kirstine H and Marie V. Nielsen. 2015. «Choosing a Pastor for the Day - Representations of the Pastor in a Contemporary Context» Journal of Empirical Theology, vol. 28, issue 2, p. 226-241. https://doi.org/10.1163/15709256-12341326

Kock, Jos de and Ronelle Sonnenberg. 2012. «Embodiment: Reflections on Religious Learning in Youth Ministry». Journal of Youth \& Theology, vol. 11, no. 1. P. 7-22.

Krupka, Bernd. 2018. «Med rom for flere stemmer? En kritisk analyse av tre nye læreverk for konfirmantundervisning i Den norske kirke». Prismet. Flerstemmig og livsnaert. No 1. Oslo: IKO p. 5-25. 
Nielsen, Marie V., Kühle, Line. 2011. «Religion and State in Denmark:

Exception among Exceptions». Nordic Journal of Religion and Society, n. 02, p. 173-188.

Pace, Judith L, Annette Hemmings, and Janet Bixby. 2006. Classroom Authority. Mahwah, NJ: Erlbaum.

Saxegaard, Fredrik. 2017. Realizing Church, Parish Pastors as Contributors to Leadership in Congregations. Dissertation for the Degree Philosophiae Doctor $(\mathrm{PhD})$, Oslo: MF Norwegian School of Theology, Akademika Publishing.

Shor, Ira. 1996. When Students Have Power. Negotiating Authority in a Critical Pedagogy. Chicago: The University of Chicago Press.

The Norwegian Church. 2010. Plan for Christian Education. God gives - we share. https://kirken.no/globalassets/kirken.no/church-of-norway/plan_trosoppl_ engelsk_2.pdf

Wertsch, James V. 1998. Mind as Action. New York: Oxford University Press. 